V. Brovkin - M. Claussen - E. Driesschaert

T. Fichefet $\cdot$ D. Kicklighter $\cdot$ M. F. Loutre

H. D. Matthews $\cdot$ N. Ramankutty $\cdot$ M. Schaeffer

A. Sokolov

\title{
Biogeophysical effects of historical land cover changes simulated by six Earth system models of intermediate complexity
}

\author{
Received: 3 January 2005/ Accepted: 2 November 2005/Published online: 7 March 2006
}

(C) Springer-Verlag 2006

\begin{abstract}
Six Earth system models of intermediate complexity that are able to simulate interaction between atmosphere, ocean, and land surface, were forced with a
\end{abstract}

V. Brovkin $(\bowtie)$

Potsdam Institute for Climate Impact Research,

P.O. Box 601203, 14412, Potsdam, Germany

E-mail: victor@pik-potsdam.de

Fax: + 49-331-2882570

\section{Claussen}

Potsdam Institute for Climate Impact

Research and Institute of Physics, Potsdam University, Potsdam, Germany

E. Driesschaert · T. Fichefet $\cdot$ M. F. Loutre

Institut d'Astronomie et de Géophysique Georges Lemaître,

Université catholique de Louvain, Louvain-la-Neuve, Belgium

D. Kicklighter

The Ecosystems Center, Marine Biological Laboratory,

Woods Hole, USA

H. D. Matthews

Department of Geography, University of Calgary, Calgary, and School of Earth and Ocean Sciences,

University of Victoria, Victoria, Canada

\section{N. Ramankutty}

Center for Sustainability and the Global Environment (SAGE), Nelson Institute for Environmental Studies, University of Wisconsin-Madison, Madison, USA

\section{Schaeffer}

Department of Global Sustainability and Climate, Netherlands Environmental Assessment Agency (MNP) - RIVM, and Climate Variability Research Division, Royal Netherlands Meteorological Institute (KNMI), De Bilt, The Netherlands

\section{A. Sokolov \\ Joint Program on the Science and Policy of Global Change, Massachusetts Institute of Technology, Cambridge, USA}

Present address: M. Claussen

Meteorological Institute, University of Hamburg,

and Max Planck Institute for Meteorology, Hamburg, Germany

Present address: M. Schaeffer

Wageningen University, Wageningen, The Netherlands scenario of land cover changes during the last millennium. In response to historical deforestation of about 18 million sq $\mathrm{km}$, the models simulate a decrease in global mean annual temperature in the range of $0.13-0.25^{\circ} \mathrm{C}$. The rate of this cooling accelerated during the 19th century, reached a maximum in the first half of the 20th century, and declined at the end of the 20th century. This trend is explained by temporal and spatial dynamics of land cover changes, as the effect of deforestation on temperature is less pronounced for tropical than for temperate regions, and reforestation in the northern temperate areas during the second part of the 20th century partly offset the cooling trend. In most of the models, land cover changes lead to a decline in annual land evapotranspiration, while seasonal changes are rather equivocal because of spatial shifts in convergence zones. In the future, reforestation might be chosen as an option for the enhancement of terrestrial carbon sequestration. Our study indicates that biogeophysical mechanisms need to be accounted for in the assessment of land management options for climate change mitigation.

\section{Introduction}

Humankind affects the climate system in many ways, particularly by modifying atmospheric gas composition and by changing land surface properties. At present, about one-third of global vegetation cover has being modified by agricultural and forestry activities (Vitousek et al. 1997). Human-induced land cover changes began probably as early as the middle Holocene, ca. 8,000 years ago, with development of slash-and-burn agriculture (Ruddiman 2003). However, the magnitude of land cover changes and their temporal dynamics on large regional scales prior to 1700 A.D. are mostly unknown. For the period after the year 1700, several global-scale assemblages of land cover changes are available on different spatial and temporal resolutions (Houghton et al. 1983; Ramankutty and Foley 1999; Klein Goldewijk 2001). 
Changes in land cover have affected the climate system through emissions of greenhouse gases such as $\mathrm{CO}_{2}$ and $\mathrm{CH}_{4}$ (biogeochemical effects) and modification of land surface albedo, evapotranspiration, and surface roughness (biogeophysical effects). Biogeophysical mechanisms of land cover changes on climate are quite complex (Foley et al. 2003; Kabat et al. 2004); hydrological and radiative effects on surface air temperature often have opposite sign, and depend on season and geographical location (Brovkin et al. 1999; Betts 2001). Land cover changes affect not only regional, but also global climate. Since land cover change is one of many anthropogenic and natural forcings operating on global scale, it is almost impossible to separate its effect on observed climate changes from effects of other forcings. Therefore, the main tool availble for evaluation of the climatic effect of land cover changes is climate system modelling.

Deforestation experiments with atmospheric general circulation models reveal a cooling effect of boreal and temperate deforestation due to albedo changes (see, e.g., Bonan et al. 1992; Bonan 1999) and a warming effect of tropical deforestation due to reduction in latent heat flux (e.g., Henderson-Sellers et al. 1993; Snyder et al. 2004). Most land-cover sensitivity simulations with atmospheric general circulation models (AGCMs) have been carried out without interactive ocean models. This is a considerable limitation, since the climate changes induced by land cover changes are modified on annual to decadal time scales by feedbacks with sea surface temperature and sea ice (e.g., Delire et al. 2001), and on decadal to centennial time scales, by feedbacks with oceanic circulation. Because AGCMs are computationally expensive, most deforestation simulations with AGCMs have been performed to assess the equilibrium response of the climate system to the forcing. A reaction of the climate system on a dynamic land cover forcing, however, is not an equilibrium response, but rather a transient one, and as such it is important to incorporate realistic land cover changes into multi-century transient simulations of climate change.

An emerging class of Earth system models of intermediate complexity (EMICs, see Claussen et al. 2002) makes it possible to evaluate the transient response of the climate system to different climate forcings on a much longer time scale than is achievable with AGCMs. Earth system models of intermediate complexity are computationally efficient and are able to carry out sensitivity simulations on centennial to millennial time scales, while at the same time maintaining realistic geography, and incorporating necessary components of climate system such as the atmosphere, ocean, land surface, and biosphere. Transient EMIC simulations with historical land cover forcing by Brovkin et al. (1999) suggested that the biogeophysical effect of historical land cover changes helps to explain observed changes in global temperature during the last 150 years. In particular, the biogeophysical cooling might have counterbalanced the warming effect of increasing atmospheric concentration of greenhouse gases during the second part of the 19th century when observations show no significant trend in temperature (Crowley 2000). Simulations with EMICs driven by natural forcings and deforestation during the last millennium performed by Bertand et al. (2002) and Bauer et al. (2003) highlighted the role of historical land cover changes in combination with the effect of natural forcings such as volcanic aerosols, and showed a good correspondence of simulated NH temperatures with temperatures reconstructed by Mann and Jones (2003). In another transient EMIC simulation, Matthews et al. $(2003,2004)$ evaluated the response of radiative and hydrological fluxes to land cover changes and estimated the short-wave radiative forcing resulting from land cover change to range from -0.08 to $-0.33 \mathrm{~W} \mathrm{~m}^{-2}$, in agreement with the range of $-0.2 \pm 0.2 \mathrm{~W} \mathrm{~m}^{-2}$ estimated by Hansen et al. (1998). While AGCM simulations with prescribed ocean SSTs by Kleidon et al. (2000) reveal little changes in global temperature in response to complete deforestation or afforestation, Renssen et al. (2003) showed that the non-linear response of ocean circulation to complete deforestation can lead to a global cooling of $3^{\circ} \mathrm{C}$. Another important aspect of land cover change is the comparison of biogeophysical effects with the biogeochemical effects of deforestation that result from $\mathrm{CO}_{2}$ emitted during land conversion (Betts 2000; Claussen et al. 2002; Brovkin et al. 2004; Matthews et al. 2004). In the present study we focus on biogeophysical effects only.

Here, we go beyond previously performed sensitivity simulations of the climate system to historical land cover changes by:

1. for the first time, applying transient deforestation experiments to models with explicit climate variability;

2. comparing results of six models forced by consistent scenarios of land cover changes;

3. analysing the response of the climate system in more detail, including seasonal and latitudinal changes of radiative and hydrological fluxes.

For consistency with previous publications, we compare the effect of land cover change with effect of historical $\mathrm{CO}_{2}$ forcing.

\section{Methods}

\subsection{Models}

The six models used in this study are: (1) CLIMBER-2 (CLIMBER hereafter, Petoukhov et al. 2000; Ganopolski et al. 2001); (2) ECBILT-CLIO-VECODE (Brovkin et al. 1997; Opsteegh et al. 1998; Goosse and Fichefet 1999); (3) the KNMI model (Opsteegh et al. 1998); (4) the MIT model (Sokolov and Stone 1998); (5) MOBIDIC (Gallée et al. 1991; Crucifix et al. 2002); and (6) UVIC (Weaver et al. 2001; Matthews et al. 2004). 
Regarding the atmosphere, ECBILT-CLIO-VECODE and KNMI models utilise 3-dimensional (3-D) quasigeostrophic AGCM, ECBILT; the CLIMBER and MIT models use 2.5-D and 2-D statistical-dynamical atmospheric models, respectively; MOBIDIC includes a 2-D quasi-geostrophic model, and UVIC uses a 2-D energymoisture balance model. The atmospheric model is the main source of explicit climate variability within ECBILT-CLIO-VECODE, KNMI, and MIT models. The CLIMBER and MIT models simulate cloudiness explicitly, and the other models apply cloudiness prescribed from present-day observations. Regarding the ocean, the ECBILT-CLIO-VECODE, MIT, and UVIC models employ 3-D oceanic GCMs, CLIMBER and MOBIDIC - zonally averaged basin models, and KNMI - mixed-layer model. All EMICs include models for sea-ice thermodynamics; CLIMBER, ECBILTCLIO-VECODE, MOBIDIC, and UVIC also simulate sea ice dynamics. More details of the atmospheric and oceanic components of the EMICs are given by Claussen et al. (2001) and in the EMIP-CO $\mathrm{CO}_{2}$ intercomparison study (see Petoukhov et al. 2005).

With respect to terrestrial vegetation cover, CLIMBER, ECBILT-CLIO-VECODE, and MOBIDIC include the dynamic vegetation model VECODE; MIT model utilises vegetation cover of Matthews (1983); KNMI model includes vegetation model from IMAGE2.2 (Alcamo et al. 1998; Leemans et al. 2002); UVIC applies aggregated vegetation classes of DeFries and Townshend (1994), with potential natural vegetation distributions for this study prescribed from Ramankutty and Foley (1999). Some details of land surface components important for land-cover sensitivity simulations are summarised in Table 1. In particular, all models include parameterisations for forest snow masking (radiative effect I) and for a decrease in snowfree albedo in the presence of trees (radiative effect II). The radiative effect $I$ is simulated in different ways. The
CLIMBER, MIT and UVIC models calculate an effective fraction of snow cover using snow and vegetation masking depths, whereas the ECBILT-CLIO-VECODE, KNMI, and MOBIDIC models reduce snow albedo in the presence of trees or woody plant functional types. Effectively, radiative effects I and II lead to an increase in land surface albedo when forest is replaced by cropland (grassland). Some models simulate the effect of vegetation cover on evapotranspiration via changes in soil water bucket depth (MIT), leaf area index (CLIMBER), or surface drag coefficient (UVIC). The KNMI model has the most advanced hydrological component that includes a coupled photosynthesis-transpiration scheme.

All models performed three transient simulations (Table 2). In the HD simulation (historical deforestation), the land cover was changed in accordance with the land cover scenario while atmospheric $\mathrm{CO}_{2}$ remained fixed at a concentration of $280 \mathrm{ppmv}$. In the $\mathrm{HC}$ simulation (historical $\mathrm{CO}_{2}$ ), atmospheric $\mathrm{CO}_{2}$ concentration was changed while land cover forcing was not involved. In simulation HDC (historical deforestation and $\mathrm{CO}_{2}$ ), both land cover and $\mathrm{CO}_{2}$ were changed. In all simulations, atmospheric, oceanic and sea-ice components of the EMICs were interactive. Vegetation dynamics in CLIMBER and MOBIDIC was switched off in order to prevent secondary effects of land cover changes in response to climatic change. Vegetation was interactive in ECBILT-CLIO-VECODE but the effect of natural vegetation dynamics on climate within this model was negligible.

Since every simulation was conducted just once with each model, the question may arise whether other realisations of the same simulations could lead to different conclusions. For models without internal atmospheric variability (CLIMBER, MOBIDIC, and UVIC), multiple realisations are not necessary as the model response is largely deterministic, so more simulations would give

Table 1 Effects of land cover changes on climate within the EMICs

\begin{tabular}{|c|c|c|c|c|c|c|}
\hline & CLIMBER & ECBILT-CLIO-VECODE & KNMI & MIT & MOBIDIC & UVIC \\
\hline $\begin{array}{l}\text { Spatial resolution } \\
\text { of the land grid } \\
\text { (lat, lon) }\end{array}$ & $10^{\circ} \times 51^{\circ}$ & $\mathrm{T} 21\left(5.6^{\circ} \times 5.6^{\circ}\right)$ & $5.6^{\circ} \times 5.6^{\circ}$ & $\begin{array}{l}4^{\circ} \times \text { zonally } \\
\text { averaged }\end{array}$ & $\begin{array}{l}5^{\circ} \times \text { two } \\
\text { continents }\end{array}$ & $1.8^{\circ} \times 3.6^{\circ}$ \\
\hline $\begin{array}{l}\text { Forest masking } \\
\text { of snow cover } \\
\text { (radiative effect I) }\end{array}$ & $\begin{array}{l}F_{\mathrm{s}}=f\left(S_{\mathrm{d}}, M_{\mathrm{d}}\right) \\
f \text {-hyperbolic } \\
\text { function }^{\mathrm{a}}\end{array}$ & $\alpha_{\mathrm{t}}=\mathrm{C} \cdot \alpha_{\text {snow }}^{\mathrm{b}}$ & $\alpha_{t}=C \cdot \alpha_{\text {snow }}$ & $\begin{array}{l}F_{\mathrm{s}}=f\left(S_{\mathrm{d}}, M_{\mathrm{d}}\right) ; \\
\mathrm{f} \text {-exponential } \\
\text { function }\end{array}$ & $\begin{array}{l}\alpha_{\mathrm{t}}=0.4 \\
\alpha_{\mathrm{g}} \sim 0.8 \\
\text { depends }\end{array}$ & $\begin{array}{l}F_{\mathrm{s}}=f\left(S_{\mathrm{d}}, M_{\mathrm{d}}\right) \\
f \text {-linear } \\
\text { function }\end{array}$ \\
\hline $\begin{array}{l}\text { Parameters that } \\
\text { modify effects of trees on } \\
\text { transpiration } \\
\text { (hydrological effect) }\end{array}$ & LAI, root depth & - & $\begin{array}{l}\text { LAI, root depth, } \\
\text { photosynthesis }\end{array}$ & Soil field capacity & - & Surface drag \\
\hline
\end{tabular}

\footnotetext{
${ }^{\mathrm{a}} F_{\mathrm{s}}$ effective fraction of snow, $S_{\mathrm{d}}$ snow depth, $M_{\mathrm{d}}$ vegetation masking depth

${ }^{\mathrm{b}} \alpha_{\mathrm{t}}$ trees albedo, $C$ reduction factor, $\alpha_{\text {snow }}$ snow albedo

$\alpha_{\mathrm{t}}$ trees albedo, $\alpha_{\mathrm{g}}$ grass albedo, LAI leaf area index

Depending on the type of trees (grassland) and seasonal dynamics of the canopy
} 
Table 2 Simulations acronyms

\begin{tabular}{llll}
\hline Acronym & Simulation & Land cover forcing & $\mathrm{CO}_{2}$ forcing \\
\hline $\mathrm{HD}$ & Historical deforestation (land cover changes), 1000-1992 & Yes $^{\mathrm{a}}$ & $\mathrm{No}$ \\
$\mathrm{HC}$ & Historical $\mathrm{CO}_{2}$ changes, 1800-1992 & No & Yes \\
$\mathrm{HDC}$ & Historical deforestation (1000-1992) and $\mathrm{CO}_{2}$ changes (1800-1992) & Yes & Yes \\
\hline
\end{tabular}

${ }^{\text {a }}$ Trees are replaced with crops in accordance with R\&F data for 1700-1992 in all models except KNMI that use HYDE dataset

${ }^{\mathrm{b}}$ Atmospheric $\mathrm{CO}_{2}$ concentration is fixed to 280 ppmv till year 1800 . For years $1800-1992, \mathrm{CO}_{2}$ is prescribed to the filtered Siple station ice core data and Mauna Loa observations (Fig. 1d)

the same answer. Regarding the models with explicit variability (KNMI, MIT, and ECBILT-CLIO-VECODE), we assume that their results were affected by the variability but that the simulations were long enough to forcing, and refer to a recent analysis of uncertainty due to multiple realisations conducted with ECBILT-CLIOVECODE (Goosse et al. 2005).

\subsection{Forcings and initial conditions}

For historical land cover changes we employ the fractional cropland data set of Ramankutty and Foley (1999) for the years 1700-1992. The time slice for the final year (1992) is shown in Fig. 1a in geographically explicit form and in Fig. 1b (upper panel) as zonally averaged over the land. The temporal dynamics of reveal a clear trend in the climate system response to the

cropland area after 1700 is seen on Fig. 1c. The Northern hemisphere $(\mathrm{NH})$ extratropics experienced rapid cropland expansion between 1850 and 1950 (particularly in North America and the Former Soviet Union), and cropland abandonment since then. The tropics have experienced the greatest cropland expansion during the 20th century, and it is continuing with increasing rapidity today. Relatively little cropland expansion occurred in the Southern hemisphere ( $\mathrm{SH}$ ) extratropics. Timing of land cover changes prior to 1700 is highly uncertain. For simplicity, a linear interpolation of data is used for years 1000-1700 assuming no cropland in year 1000 .

The $R \& F$ data are aggregated to the spatial resolution of the models. Changes in cropland area are interpreted as changes in tree area, although, in general, deforestation and increase in crop fraction are not the same. For example, the latter might be due to conversion
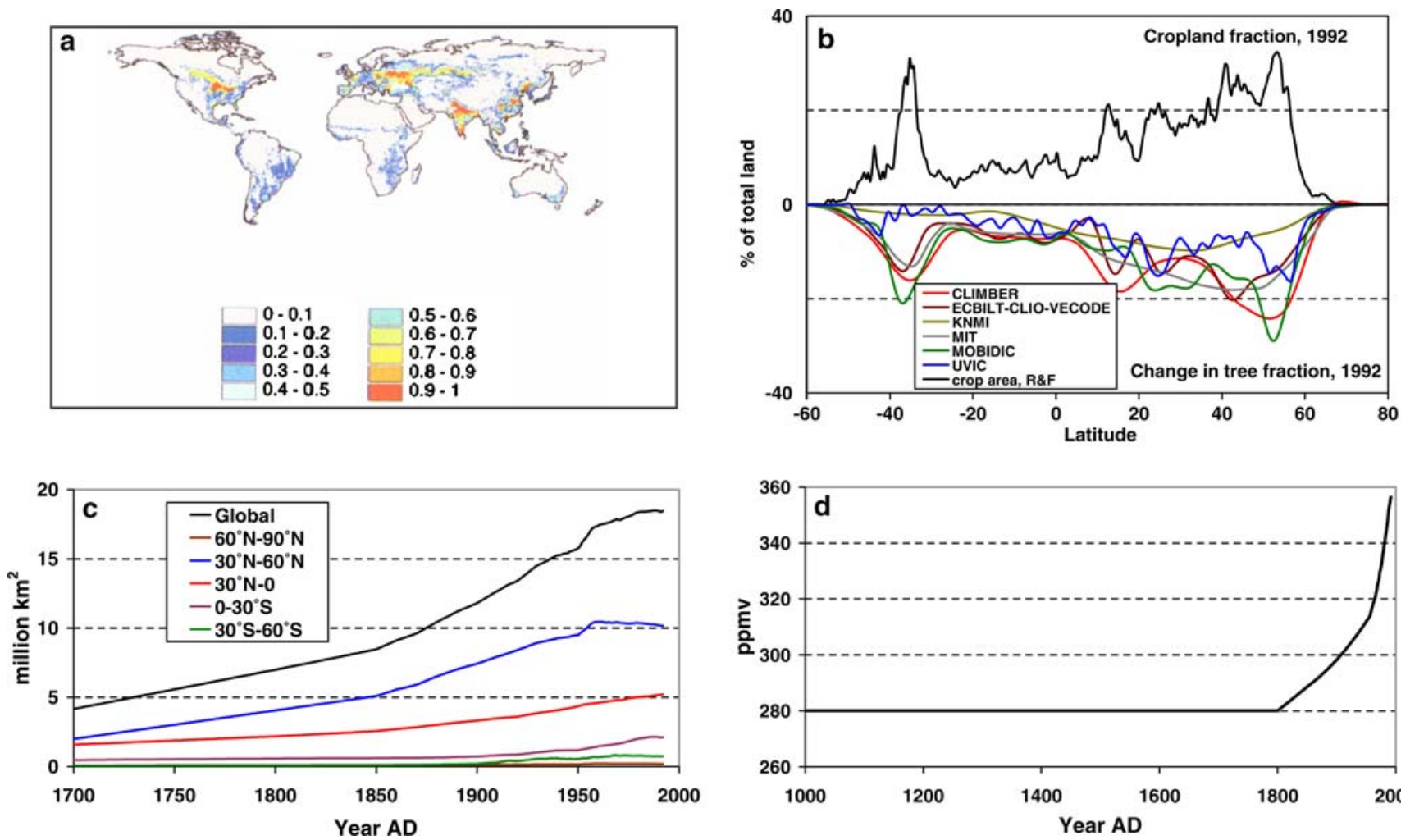

Fig. 1 Forcings used in the simulation. Cropland map in year 1992, R\&F. b Zonal distribution of changes in tree cover within thea models from year 1000 to 1992 (low panel) versus cropland fraction of R\&F for year 1992 (top panel). For the KNMI model, the changes are from 1700 to 1992 . c Changes in global crop area, million $\mathrm{km}^{2}$, years $1700-1992, \mathrm{R} \& \mathrm{~F}$. d CO $\mathrm{CO}_{2}$ dynamics 
Table 3 Changes in annual mean global and NH surface air temperature during the last decade of simulation (1983-1992) relative to the pre-industrial equilibrium, ${ }^{\circ} \mathrm{C}$

\begin{tabular}{lllll}
\hline Model & $\Delta T_{\mathrm{HD}}$ & $\Delta T_{\mathrm{HC}}$ & $\Delta T_{\mathrm{HDC}}$ & $\Delta T_{\mathrm{HDC}}\left(\Delta T_{\mathrm{HD}}+\Delta T_{\mathrm{HC}}\right)$ \\
\hline CLIMBER & $-0.24 /-0.31^{\mathrm{a}}$ & $0.52 / 0.58$ & $0.29 / 0.25$ & $0.01 /-0.02$ \\
ECBILT-CLIO-VECODE & $-0.13 /-0.23$ & $0.27 / 0.36$ & $0.17 / 0.14$ & $0.03 /-0.01$ \\
MIT & $-0.14 /-0.19$ & $0.42 / 0.51$ & $0.37 / 0.35$ & $0.09 / 0.03$ \\
MOBIDIC & $-0.25 /-0.36$ & $0.34 / 0.4$ & $0.10 / 0.05$ & $0.01 / 0.01$ \\
UVIC & $-0.17 /-0.23$ & $0.62 / 0.68$ & $0.46 / 0.47$ & $0.01 / 0.02$ \\
\hline
\end{tabular}

${ }^{\mathrm{a}}$ Global/northern hemisphere

of grassland, as happened in the Great Plains region of the USA. Nevertheless, the historical increase in crop area is approximately equal to the decrease in forest area on the global scale (Ramankutty and Foley 1999), although on the regional scale the differences between changes in forest and cropland fractional area could be quite substantial.

Each model, with the exception of KNMI, begins with a natural vegetation cover. The CLIMBER, ECBILT-CLIO-VECODE, and MOBIDIC models simulate vegetation cover in equilibrium with the preindustrial climate, whereas the UVIC and MIT models use potential vegetation datasets. This difference in initial conditions affects the land cover forcing within the models. For example, if the tree fraction at the beginning of a simulation is lower than crop fraction at the end for a grid cell, than the tree fraction is prescribed to zero (or to minimum tree fraction) after the given year. This, as well as a differences in spatial resolution (see Table 1), explains why changes in forest (tree) cover simulated at the year 1992 (Fig. 1b, bottom panel) differ among the models.

Simulations with the KNMI model begin in the year 1700 from the vegetation cover generated by the IMAGE model for this year. Historical land cover changes used within the IMAGE model are based on the HYDE dataset (Klein Goldewijk 2001). While this dataset differs from the $\mathrm{R} \& \mathrm{~F}$ dataset, it is based on similar sources of information about land cover changes in the past. Applications of both datasets for the CLIMBER model revealed similar dynamics of tree fraction during yrs
1700-1990 (Brovkin et al. 2004). Since about one-third of land cover changes occurred prior to 1700 , the differences in tree area changes between the KNMI (for which changes are from 1700 to 1992) and the other models (changes are from 1000 to 1992) may be explained by the differences in initial states (Fig. 1b).

Atmospheric $\mathrm{CO}_{2}$ concentration in simulations $\mathrm{HC}$ and HDC is fixed at a constant level of 280 ppmv during the years 1000-1800. The trend of $\mathrm{CO}_{2}$ for the period 1800-1992 is taken from Neftel et al. (1994) and Keeling and Whorf (2005), and is shown in Fig. 1d. In all models, initial conditions are taken from pre-industrial equilibrium simulations using present-day orbital forcing and insolation, absence of volcanic eruptions and land cover changes (except KNMI), and an atmospheric $\mathrm{CO}_{2}$ level of 280 ppmv.

\section{Results}

3.1 Transient response of the Northern hemisphere temperature in the HD simulation

During the last millennium, land areas in the NH have been deforested to a much larger extent than in the south. In addition, the NH contains more landmasses that respond to external climatic forcings (e.g., changes in insolation or $\mathrm{CO}_{2}$ concentration) more rapidly than does the thermally inert ocean (IPCC 2001). Consequently, the effect of land cover changes on climate is more pronounced in the NH. In response to the his-
Fig. 2 Changes in mean annual surface air temperature $\left({ }^{\circ} \mathrm{C}\right)$ for $\mathrm{NH}, 20$ years moving average, simulation HD

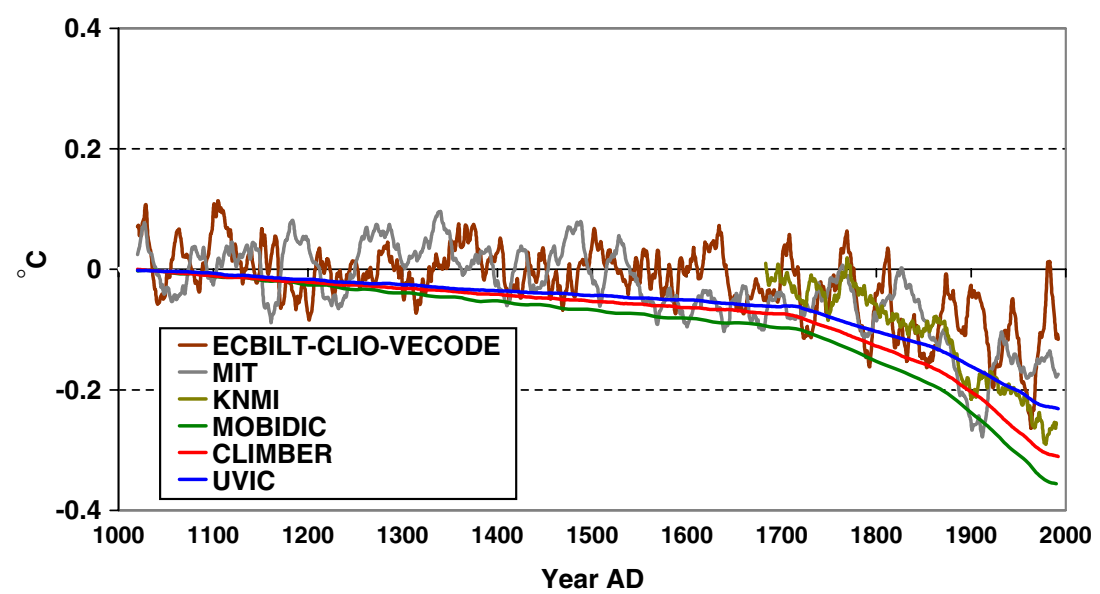



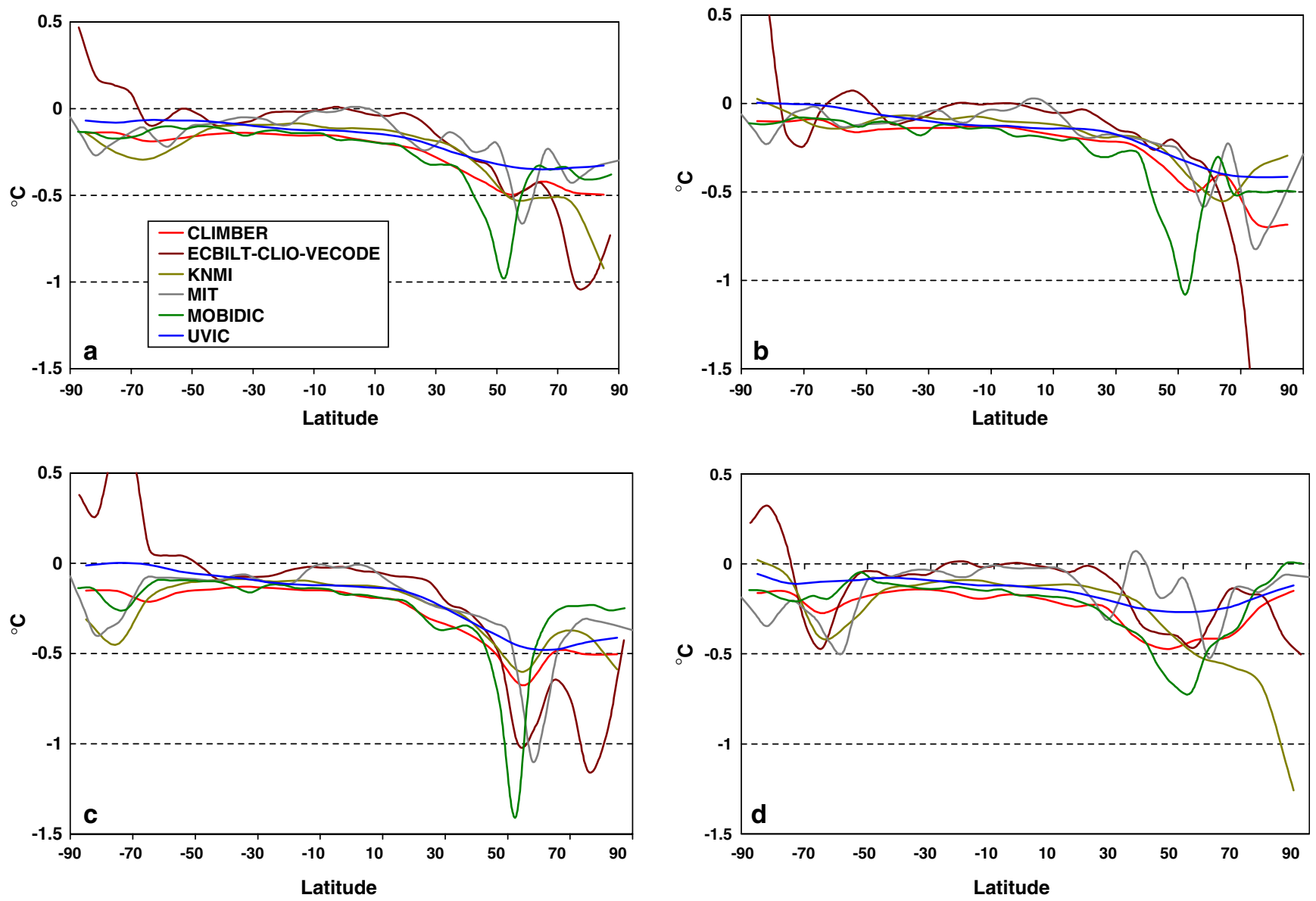

Fig. 3 Zonally averaged changes in surface air temperature $\left({ }^{\circ} \mathrm{C}\right)$ for different seasons, simulation HD, difference between final and initial 10-year average. a Annual; b December-February; c March-May; d June-August

torical land cover changes, all the models simulate a decline in the $\mathrm{NH}$ mean annual temperature of between 0.19 and $0.36^{\circ} \mathrm{C}$ at the end of the simulation relative to pre-industrial (Table 3). Among the models, MOBIDIC and CLIMBER show the strongest cooling (0.36 and $0.31^{\circ} \mathrm{C}$, respectively), while the temperature decrease within the MIT model is the weakest $\left(0.19^{\circ} \mathrm{C}\right)$. Cooling within UVIC and ECBILT-CLIO-VECODE models $\left(0.23^{\circ} \mathrm{C}\right)$ as well as $\mathrm{KNMI}$ model $\left(0.26^{\circ} \mathrm{C}\right)$ is close to the average response of the six models of $0.26^{\circ} \mathrm{C}$. Since the ECBILT-CLIO-VECODE, KNMI, and MIT models possess internal climate variability, averaging of the results over the last 10 years might not be fully representative of the trend. However, the general cooling tendency for these models is clearly seen in Fig. 2. The rate of this cooling accelerates during the 19th century, reaches a maximum in the first part of the 20th century, and declines at the end of the 20th century. The trend is explained by the temporal and spatial dynamics of the land cover changes, as the effect of deforestation on temperature is less pronounced for tropics than for temperate regions, and reforestation in northern temperate areas during the second part of the 20th century partly offsets the cooling trend. Indeed, cropland expansion in some parts of the $\mathrm{NH}$ extratropics and the tropical regions were rapid during the first half of the 20th century (Fig. 1c). However, in the second half of the 20th century, while croplands expanded further in the tropics, they were abandoned in some parts of the NH extratropics (eastern North America, Europe, and China) and replaced by regrowing forests.

3.2 Effects of historical land cover changes on zonal and seasonal temperature and albedo

The cooling effect of land cover changes on NH temperature increases monotonically with time in the models without internal climatic variability, and fluctuates in the models with explicit climatic variability (Fig. 2). To evaluate the effect of land cover changes on seasonal and latitudinal temperature, we analyse a difference between the last decade of simulations (1983-1992) and the initial state (that corresponds to the natural vegetation cover in year 1000 for all models except KNMI which began from an initial state equilibrated with vegetation cover as of year 1700) assuming this is representative for models with explicit climatic variability. The effect of land cover changes on zonally averaged air surface temperature is shown on Fig. 3. In the annual average, 
all models show a substantial cooling in the northern extratropics (above $40^{\circ} \mathrm{N}$ ) of between 0.2 and $0.5^{\circ} \mathrm{C}$, and one model, MOBIDIC, shows a cooling of up to $1^{\circ} \mathrm{C}$ at $50^{\circ} \mathrm{N}$ (Fig. 3a). A decrease in temperature to the north of the deforested areas (above $60^{\circ} \mathrm{N}$ ) is not due to direct forcing but rather because of changes in SSTs and sea ice cover.

The response in the tropical regions and in the $\mathrm{SH}$ is less significant. This is explained by the geographical distribution of the forcing and the much larger land masses in the $\mathrm{NH}$ relative to the $\mathrm{SH}$. For example, the maximum land cover forcing in the $\mathrm{SH}$ around $40 \mathrm{~s}$ (Fig. 1b) has no effect on zonally averaged temperature since the land fraction in this latitude is negligible. In the tropical regions, the MIT model and ECBILT-CLIOVECODE show no changes in temperature while the other models simulate a cooling of about $0.2^{\circ} \mathrm{C}$. Similar model differences in the tropics are seen for seasonal temperatures as well (see Fig. 3b-d). Let us note that response of the ECBILT-CLIO-VECODE model in the tropics to external forcings is usually quite weak (see, e.g., Petoukhov et al. 2005).

During the northern spring (MAM, Fig. 3c), the effect of land cover changes is most pronounced in all the models in the high northern latitudes with cooling reaching $1.4,1.1$, and $1.0^{\circ} \mathrm{C}$ in the MOBIDIC, MIT, and
ECBILT-CLIO-VECODE models, respectively. The other models show response between 0.5 and $0.7^{\circ} \mathrm{C}$. During June-August, the cooling is significant but not as substantial as during March-May (Fig. 3d). A cooling in the southern high latitudes is mostly explained by an increase in sea ice in the Southern ocean.

The significant cooling in the northern high latitudes is explained mostly by changes in land surface albedo due to the snow-masking effect of forests (Fig. 4). Around $50^{\circ} \mathrm{N}$, annually averaged albedo has been increased by 0.05-0.06 in CLIMBER and MOBIDIC models, and by about 0.02 in the other models (Fig. 4a). The strong increase in the albedo of CLIMBER and MOBIDIC corresponds to a strong deforestation in this region (about $25-30 \%$ of land, see Fig. 1b). The lower surface albedo change simulated by UVIC is likely a direct consequence of the differences in cropland forcing evident in Fig. 1b, though differences in the model parameterisations of surface albedo also contribute to the spread in surface albedo changes between the six models. During December-February the increase in surface albedo is rather high and approaches $0.07,0.09$, and 0.10 in MIT, MOBIDIC, and CLIMBER models, respectively (Fig. 4b). Since the amount of incoming solar radiation during the winter season is quite small, this albedo change has only a moderate effect on tempera-
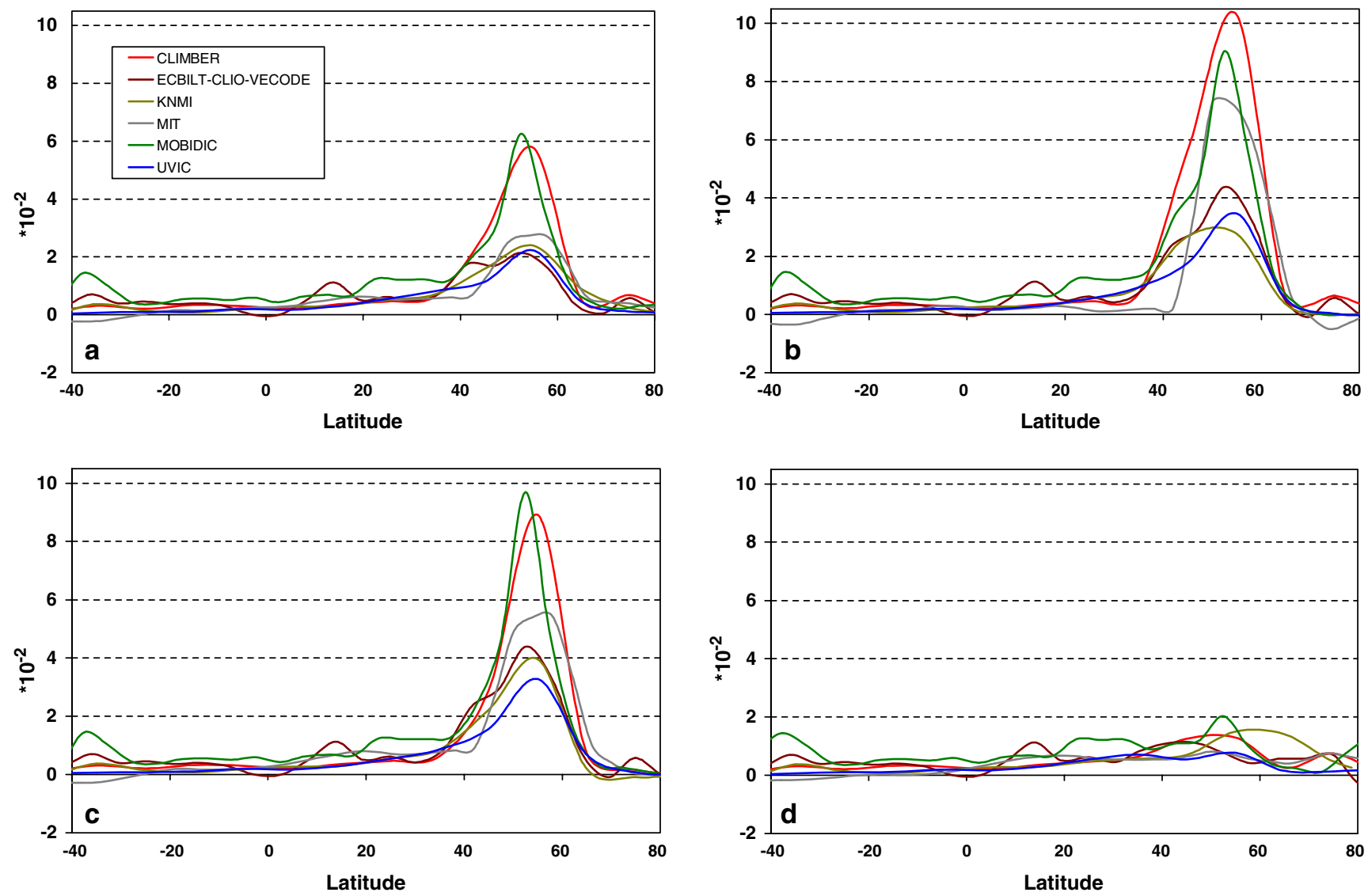

Fig. 4 Zonally averaged changes in land surface albedo $\left(10^{-2}\right)$ for different seasons, simulation HD, difference between final and initial 10 year averages. a Annual; b December-February; c March-May; d June-August 

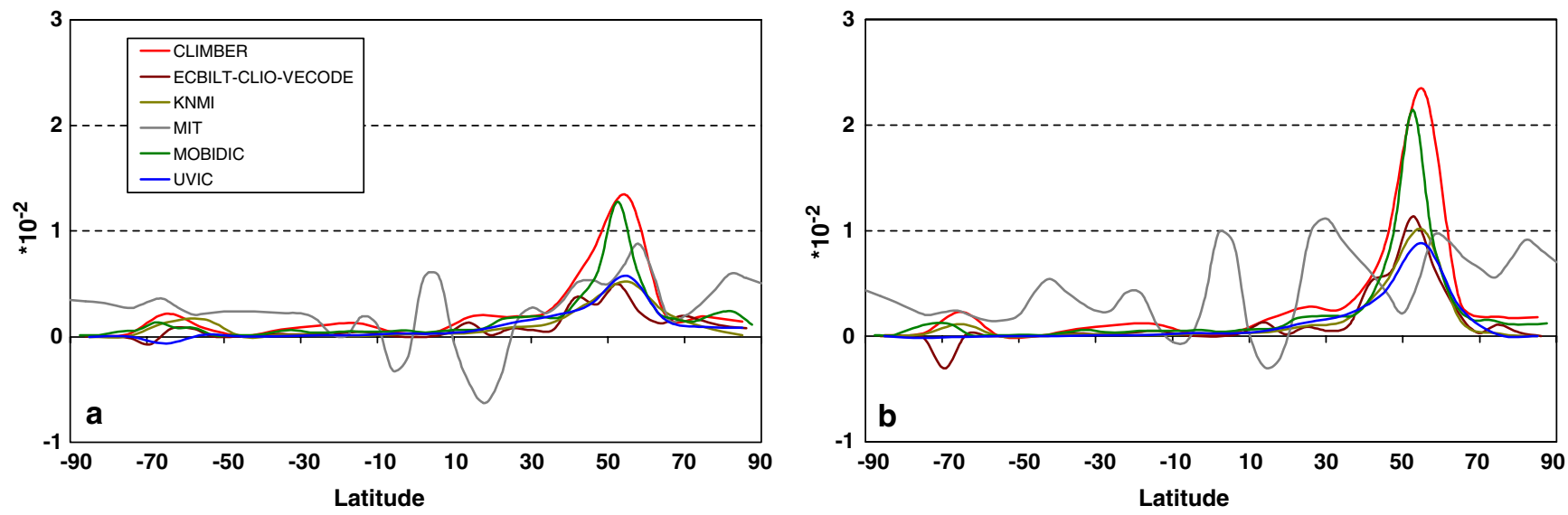

Fig. 5 Zonally averaged changes in planetary albedo $\left(10^{-2}\right)$, simulation HD, difference between final and initial 10-year averages. a Annual; b March-May

ture (see Fig. 3b). During March-May (the snow thawing season), the increase in the albedo in the northern high latitudes is very pronounced (Fig. 4c). The albedo changes become small during the summer season since the deforested areas are snow free and radiative effect I (snow-masking of forest) is absent (Fig. 4d). Radiative effect II (higher albedo of grassland relative to forests in the absence of snow) results in a land albedo increase of about 0.01 .

Changes in planetary albedo (Fig. 5) reflect changes in surface albedo and cloud cover (two models-MIT and CLIMBER - explicitly simulate interactive cloud cover while the others do not). Annually averaged changes in the albedo are well below 0.01 in all regions except at latitudes around $50^{\circ} \mathrm{N}$, where the signal is stronger, especially in the CLIMBER and MOBIDIC models. The wave-like pattern in the changes in planetary albedo simulated by the MIT model is associated with changes in cloud cover, which, in turn, are caused by small changes in position and intensity of the Hadley circulation cell. A similar pattern is present in the transient response of the MIT model to the $\mathrm{CO}_{2}$ increase, although it is almost invisible in the equilibrium re-

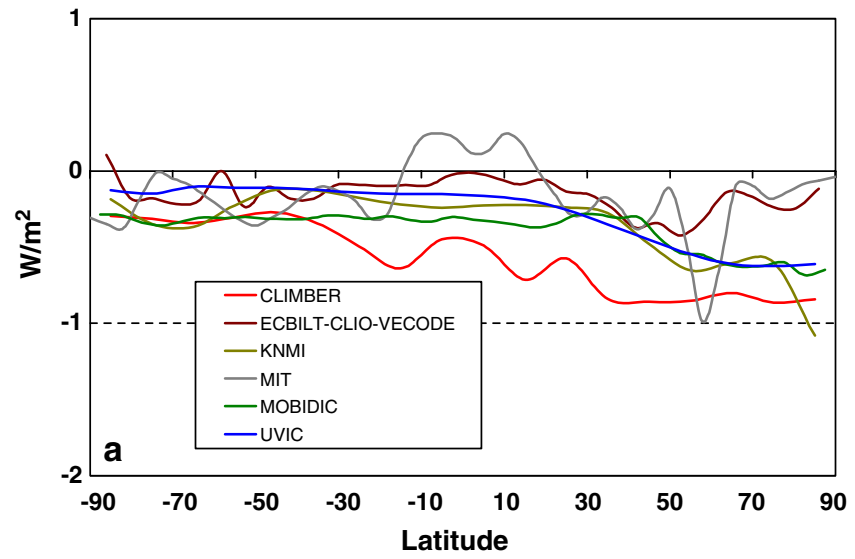

sponse of the model to the $\mathrm{CO}_{2}$ forcing (Petoukhov et al. 2005).

3.3 Effects of historical land cover changes on zonal outgoing long-wave radiation and evapotranspiration (evaporation)

In response to the land cover changes, outgoing longwave radiation (OLWR) decreases by up to $0.6 \mathrm{~W} \mathrm{~m}^{-2}$ in the annual mean. This decrease is most pronounced in the NH (Fig. 6a); CLIMBER in particular shows a stronger reduction in OLWR than do the other models. The reduction is mostly explained by a decrease in the surface air temperature (Fig. 3a). The MIT model again shows a wavy response which is most pronounced during the spring season (Fig. 6b). The other high-resolution models (ECBILT-CLIO-VECODE and KNMI) do not demonstrate this spatial variability, presumably due to prescribed cloudiness.

In most cases, trees have higher transpiration than herbaceous plants due to their higher leaf area index and deeper roots, which transport water from the deep soil

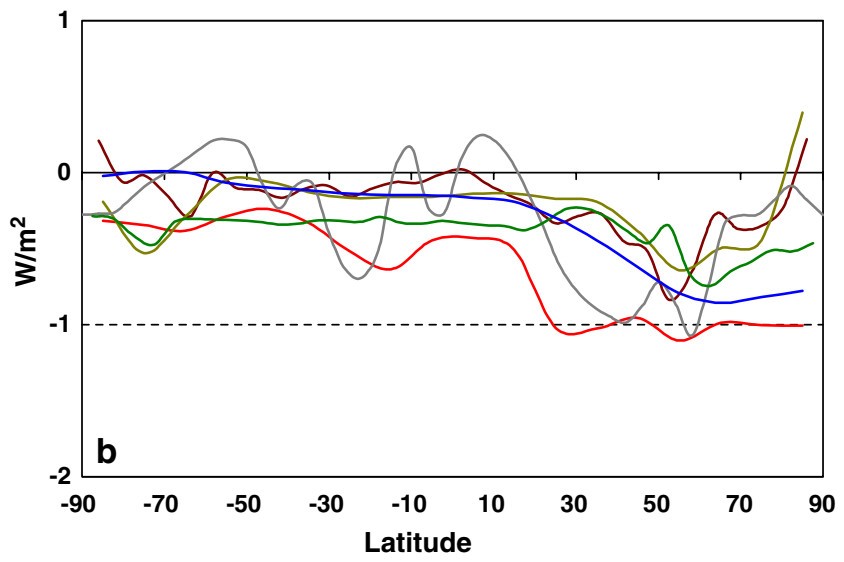

Fig. 6 Zonally averaged changes in outgoing long-wave radiation $(O L W R)\left(\mathrm{W} \mathrm{m}^{-2}\right)$, simulation $\mathrm{HD}$, difference between final and initial 10-year averages. a Annual; b March-May 

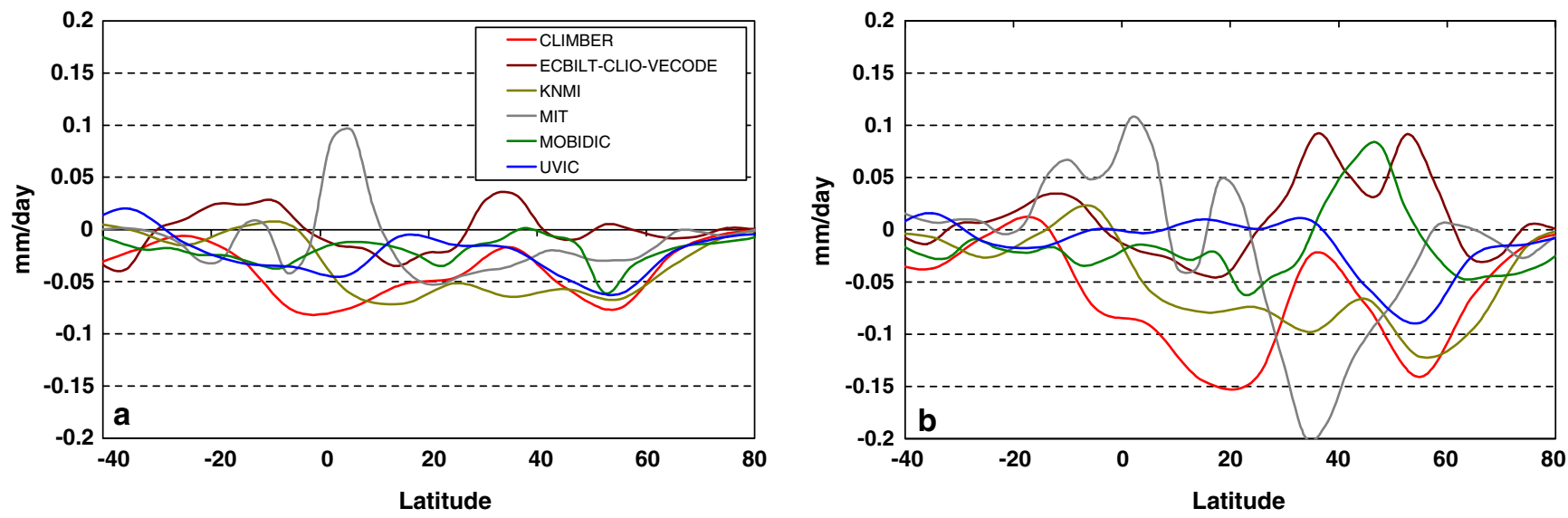

Fig. 7 Zonally averaged changes in land evapotranspiration (evaporation), mm/day, for simulation HD, difference between final and initial 10-year averages. a Annual; b June-August

layers. This hydrological mechanism is build into several EMICs (CLIMBER, MIT, and KNMI-see Table 1). In the UVIC model, evaporation is parameterised based on surface roughness and the larger roughness length associated with trees also results in higher evapotranspiration in forested areas. Evaporation over land is also controlled by changes in hydrological cycle, on the first order by changes in precipitation and temperature: decrease in either of these factors leads to reduced evaporation. This is the main mechanism behind the effect of deforestation on evaporation in the ECBILT-CLIOVECODE, UVIC, and MOBIDIC models, which do not simulate transpiration processes. In general, one can expect that in response to deforestation and simulated cooling, the models would simulate a decrease in evapotranspiration. Indeed, in response to reduced tree (forest) cover, four out of the six models simulate a reduction in annually averaged evapotranspiration over land (Fig. 7a). During the northern summer, changes in evapotranspiration are highly varied between models (Fig. 7b). During this season, the amplitude of changes is stronger than in the annual average since the hydrological cycle is most affected by vegetation growth during the summer growing season. The ECBILT-CLIOVECODE and MOBIDIC models show a substantial increase in evaporation in temperate northern latitudes, whereas the MIT model reveals some increase in evapotranspiration in the tropics that is counterbalanced by strong reduction in the northern subtropics. While the wavy tropical pattern in the MIT model is in line with the simulated shift in the Hadley circulation cell, changes in ECBILT-CLIO-VECODE and MOBIDIC are driven by changes in temperature and precipitation. For example, increased evaporation between 30 and $60^{\circ} \mathrm{N}$ in ECBILT-CLIO-VECODE is due to simultaneous decrease in temperature and increase in precipitation over the Asian coast and Far East. In this region, summer evaporation within the model is limited by the lack of available water in the soil bucket. As precipitation increases, there is more water available for evapo- ration in the soil and evaporation can increase even if temperature decreases. In MOBIDIC, the increase in summer evaporation around $50^{\circ} \mathrm{N}$ is associated with increased precipitation over the continents. Models that do not explicitly simulate the seasonal cycle of vegetation growth, like the UVIC model, show lower seasonal variability in modelled evapotranspiration changes.

\subsection{Effects of land cover and $\mathrm{CO}_{2}$ forcings on global} temperature and precipitation

Since more than half of the global land cover changes has occurred since the industrial revolution, it is important to compare the effects of historical land cover with the effects of $\mathrm{CO}_{2}$ increases. We analyse results from five of the presented EMICs (the KNMI model was excluded because the version with mixed layer ocean used in the present study has an unrealistically high $\mathrm{CO}_{2}$ sensitivity). A comparison with observed temperature changes is not included here since several historical forcings (insolation, volcanism, non- $\mathrm{CO}_{2}$ greenhouse gases, and aerosols) are not accounted for.

In response to land cover changes only (HD), global temperature is decreased by $0.13-0.25^{\circ} \mathrm{C}$ (Table 3); cooling within the $\mathrm{KNMI}$ model, $0.17^{\circ} \mathrm{C}$, falls within this range. Simulated transient changes in global temperature (Fig. 8a) qualitatively follow those for the Northern hemisphere (Fig. 2) while the quantitative response of the Northern hemisphere is stronger (see discussion in the Sect. 3.1). All the models simulate a decrease in global precipitation, albeit quite small (Fig. 8b); CLIMBER shows the strongest reduction in precipitation in particular due to the inclusion of interactive cloud cover.

In response to $\mathrm{CO}_{2}$ forcing only $(\mathrm{HC})$, all models demonstrate a similar trend of global temperature increase. However, the magnitude of the increase differs among the models with ECBILT-CLIO-VECODE simulating the smallest temperature increase $\left(0.36^{\circ} \mathrm{C}\right)$ and 

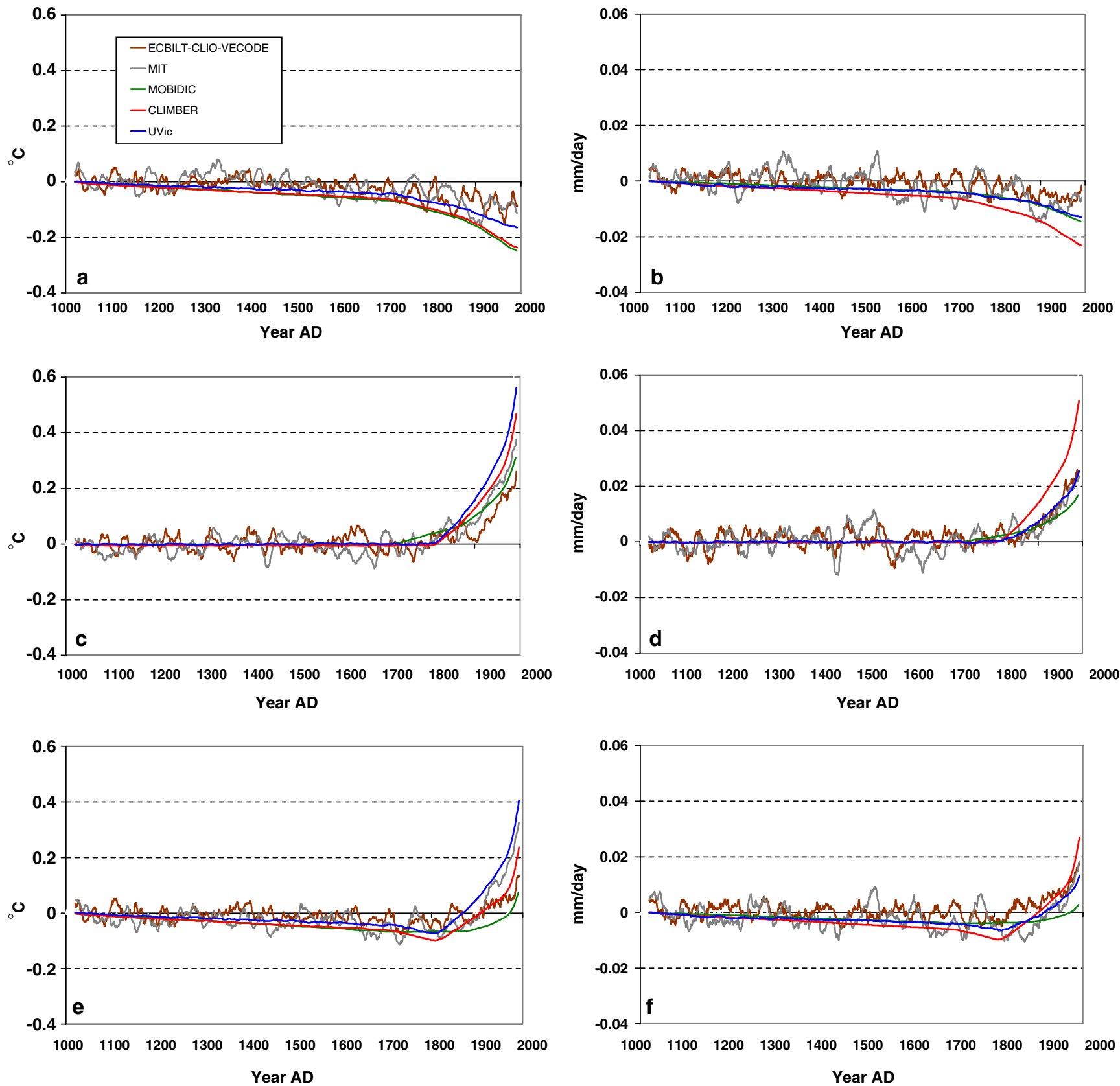

Fig. 8 Simulated climatic changes in the $\operatorname{HD}(\mathbf{a}, \mathbf{b}), \mathrm{HC}(\mathbf{c}, \mathbf{d})$, and $\operatorname{HDC}(\mathbf{e}, \mathbf{f})$ simulations, 20-year moving average. a, $\mathbf{c}$, and $\mathbf{e}-$ changes in mean annual surface air temperature $\left({ }^{\circ} \mathrm{C}\right), \mathbf{b}, \mathbf{d}$, and $\mathbf{f}-$ changes in mean annual precipitation (mm/day)

the UVIC model simulating the largest $\left(0.68^{\circ} \mathrm{C}\right)$ (Fig. $8 \mathrm{c}$, see more details in EMIP-CO ${ }_{2}$ intercomparison study by Petoukhov et al. (2005). In the HC simulation, the global hydrological cycle is enhanced in all models and precipitation increases with CLIMBER showing a response almost two times stronger than in the other models (Fig. 8d). Despite substantial differences among the models, they all fall within the scatter of precipitation to temperature changes of the AMIP GCMs driven by 2 times $\mathrm{CO} 2$ forcing (see Fig. 7 in Petoukhov et al. 2005).

In response to the combination of land cover and $\mathrm{CO}_{2}$ forcings in simulation HDC, all models show an increase in temperature at the end of the simulation (Fig. 8e). The models reveal a temperature minimum in the first half of the 19th century associated with the onset of $\mathrm{CO}_{2}$ forcing which begins to offset the deforestation forcing after the year 1800 (Fig. 8e). In the 20th century, the $\mathrm{CO}_{2}$-induced warming dominates over the cooling associated with land-cover changes. The same qualitative pattern also holds for precipitation (Fig. 8f).

In models without internal climatic variability (CLIMBER, MOBIDIC, and UVIC) the sum of global temperature changes in $\mathrm{HD}$ and $\mathrm{HC}$ simulations is very close to the temperature changes in the HDC simulation (see Table 3). This indicates a linear additivity of model 
forcings at the global scale, though non-linearities are present on regional scales. The MIT model and ECBILT-CLIO-VECODE model show some non-linearity at the global scale (the effect of combined forcing is stronger than the sum of effects of each forcing). For example, for the MIT model $\Delta T_{\mathrm{HDC}}=0.37^{\circ} \mathrm{C}$ while $\Delta T_{\mathrm{HD}}+\Delta T_{\mathrm{HC}}=0.28^{\circ} \mathrm{C}$ (Table 3); the difference is mainly caused by discontinuity in the sea ice changes in the SH (see Fig. 6f in Petoukhov et al. 2005). Also, both models posses internal climate variability that could be responsible for this non-additive response as well.

\section{Discussion}

In the HD simulation, the EMICs reveal a biogeophysical cooling of $0.13-0.25^{\circ} \mathrm{C}$ at the global scale (Table 3). This range is within the range of cooling reported by previous studies (Table 4). As noted in the introduction, most previous AGCM experiments with land cover changes have been performed in equilibrium simulations with prescribed SSTs and sea ice; this fixes the mean climate state and severely limits the global temperature response. The advantage of using AGCMs is the ability to simulate high-resolution atmospheric dynamics like planetary waves. Simulations with the
NCAR model (Chase et al. 2000; Pitman and Zhao 2000; Zhao and Pitman 2002) suggest that teleconnections associated with wave dynamics may offset the direct effect of albedo changes and result in a pronounced warming in northern temperate and high latitudes that leads to a global warming of $0.05-0.06^{\circ} \mathrm{C}$. However, experiments with the HadCM model reveal prevailing cooling effect of $0.02^{\circ} \mathrm{C}$ on the global scale (Betts 2001).

In comparison with GCMs, the EMICs presented here have simplified parameterisations and often coarse resolution, but they are capable of being run in multicentennial experiments with all the important components (atmosphere, land, and ocean) interacting with each other. Due to this interaction, the direct effect of land cover changes is amplified by positive feedbacks, in particular those involving sea-ice and water vapour. Four out of six models use prescribed cloud cover and therefore do not simulate cloud feedback, which, while being highly uncertain, is positive in most of the AGCMs (Colman 2003). In the absence of the cloud feedback, the climate response is likely to be underestimated in the HC simulation, but the effect in the HD simulation is not as clear. Most AGCMs simulate increases in cloud cover in response to surface cooling which decreases the impact of changes in surface albedo on net radiative fluxes at the top of the atmosphere. This would

Table 4 Biogeophysical response of climate system to land cover changes

\begin{tabular}{|c|c|c|c|c|c|c|}
\hline Publication & Model & Land cover dataset & $\begin{array}{l}\text { Ocean } \\
\text { mode }\end{array}$ & Time frame & $\begin{array}{l}\text { Global SAT } \\
\text { changes, }{ }^{\circ} \mathrm{C}\end{array}$ & Main features \\
\hline \multicolumn{7}{|c|}{ Historical land cover changes } \\
\hline Betts (2001) & HadAM3 & $\begin{array}{l}\text { (Wilson and } \\
\text { Henderson-Sellers 1985) }\end{array}$ & Fixed & \multicolumn{2}{|c|}{$\begin{array}{l}\text { Preindust-rial, }-0.02 \\
1990 \mathrm{~s}\end{array}$} & $\begin{array}{l}\text { Winter cooling, } \\
\text { summer warming }\end{array}$ \\
\hline $\begin{array}{l}\text { Pitman and } \\
\text { Zhao (2001); } \\
\text { Zhao and } \\
\text { Pitman (2002) }\end{array}$ & NCAR CCM3 & $\begin{array}{l}\text { BATS, } \\
\text { (Nemani et al. 1996) }\end{array}$ & \multicolumn{3}{|c|}{$\begin{array}{l}\text { Mixed layer Preindust-rial, } 0.06 \\
1990 \mathrm{~s}\end{array}$} & $\begin{array}{l}\text { Warming in high } \\
\text { northern latitudes }\end{array}$ \\
\hline $\begin{array}{l}\text { Feddema et al. } \\
(2005)\end{array}$ & DOE-PCM & IMAGE 2.2 & Dynamic & \multicolumn{2}{|c|}{$\begin{array}{l}\text { Preindust-rial, }-0.39 \\
\text { 1990s }\end{array}$} & $\begin{array}{l}\text { Strong cooling within } \\
\text { deforested regions } \\
\text { in mid-latitudes }\end{array}$ \\
\hline $\begin{array}{l}\text { Matthews et al. } \\
(2004)\end{array}$ & UVIC & R\&F, HYDE & Dynamic & $1700-1992$ & -0.06 to -0.22 & $\begin{array}{l}\text { Global cooling } \\
\text { sensitive to the land } \\
\text { dataset and cropland } \\
\text { albedo }\end{array}$ \\
\hline $\begin{array}{l}\text { Brovkin et al. } \\
(2004)\end{array}$ & CLIMBER & R\&F, HYDE & Dynamic & $1000-2000$ & $\begin{array}{l}-0.26(\mathrm{R} \& \mathrm{~F}) \\
-0.27(\mathrm{HYDE})\end{array}$ & $\begin{array}{l}\text { Strong cooling in spring, } \\
\text { weak cooling in summer }\end{array}$ \\
\hline This study & 6 EMICs & $\mathrm{R} \& \mathrm{~F}$ & Dynamic & $1000-1992$ & -0.13 to -0.25 & $\begin{array}{l}\text { Cooling, especially strong } \\
\text { in temperate northern } \\
\text { latitudes }\end{array}$ \\
\hline \multicolumn{7}{|c|}{ Future land cover changes } \\
\hline $\begin{array}{l}\text { De Fries et al. } \\
(2002)\end{array}$ & $\mathrm{CSU}$ GCM $+\mathrm{Sib}^{2}$ & $\begin{array}{l}\text { IPCC SRES B } \\
\text { (RIVM) }\end{array}$ & Fixed & 2000,2050 & $\begin{array}{l}0.1(\mathrm{DJF}) \\
-0.6(\mathrm{JJA})^{\mathrm{a}}\end{array}$ & Warming in tropics \\
\hline Sitch et al. (2005) & CLIMBER2-LPJ & $\begin{array}{l}\text { IPCC SRES A2, } \\
\text { B1 (RIVM) }\end{array}$ & Dynamic & $1990-2100$ & $\begin{array}{c}-0.15(\mathrm{~A} 2) \\
0.05(\mathrm{~B} 1)\end{array}$ & $\begin{array}{l}\text { Cooling for A2, } \\
\text { warming for } \mathrm{B} 1\end{array}$ \\
\hline
\end{tabular}

\footnotetext{
${ }^{\mathrm{a}}$ Average over the land
} 
reduce forcing due to deforestation, although the signal may vary geographically and seasonally. On average, EMICs used in this study show somewhat stronger global response to the land cover forcing than do the GCMs. The spread in the EMICs' response presented in previously published sensitivity simulations $(-0.06$ to $-0.35^{\circ} \mathrm{C}$, see Table 4 ) is likely caused by different model parameterisations as well as by different reconstruction of land cover changes.

The biogeophysical cooling reported here could be directly expressed in the radiative forcing terms. For ECBILT-CLIO-VECODE, a decrease in radiative forcing in response to $R \& F$ land cover changes amounts to 0.14 and $0.20 \mathrm{~W} \mathrm{~m}^{-2}$ for the periods $1700-1992$ and 1000-1992, respectively, as estimated from simulations carried out by Goosse et al. (2005). For the MIT model, an approach based on changes in short-wave radiation at the top of the atmosphere reveals a decrease in radiative forcing in the HD simulation by $0.35 \mathrm{~W} \mathrm{~m}^{-2}$ for the years 1000-1992. For CLIMBER-2, changes in radiative forcing due to $\mathrm{R} \& \mathrm{~F}$ land cover changes between 1000 and 1992 have been estimated to be $-0.5 \mathrm{~W} \mathrm{~m}^{-2}$ (Sitch et al. 2005). For the MIT and CLIMBER-2 models, changes in radiative forcing are slightly modified due to effect of interactive cloudiness. Matthews et al. (2004) estimated the radiative forcing in the UVic model as $-0.2 \mathrm{~W} \mathrm{~m}^{-2}$ using the R\&F dataset. This estimate is well within the range of Myhre and Myhre (2003), who estimated a range of -0.29 to -0.02 for the $\mathrm{R} \& \mathrm{~F}$ dataset, using a high-resolution radiative transfer model and three albedo datasets. Myhre and Myhre (2003) also reported a radiative forcing range from -0.66 to $0.1 \mathrm{~W} \mathrm{~m}^{-2}$ for different versions of the HYDE dataset. While CLIMBER-2 simulations reveal almost no difference in biogeophysical effects between the R\&F and HYDE datasets (Brovkin et al. 2004), in the UVic model, radiative forcing was calculated at $-0.28 \mathrm{~W} \mathrm{~m}^{-2}$ when the HYDE dataset was used, compared to $-0.2 \mathrm{~W} \mathrm{~m}^{-2}$ for $\mathrm{R} \& \mathrm{~F}$. We suppose that the differences among the EMIC and GCM estimates are caused by: (a) different parameterisation of the vegetation influence on land surface albedo; (b) different approaches for estimation of radiative forcings in EMIC simulations since, in some cases, feedbacks were not switched off (like interactive cloudiness within CLIMBER-2 and MIT models).

A cooling in the tropical region in the HD simulation by up to $0.2^{\circ} \mathrm{C}$, at a first glance, contradicts results of AGCM simulations and observations, which show pronounced temperature increase over deforested tropical land due to the decreased ratio of latent to sensible heat fluxes (Henderson-Sellers et al. 1993; Snyder et al. 2004). However, most of the AGCM simulations were conducted with prescribed SSTs, which modify the global response considerably. Prescribed SSTs neglect the water vapour feedback over the sea surface and may reverse the sign of zonally averaged temperature changes in the tropics (Ganopolski et al. 2001). In the AGCM simulation with interactive mixed layer ocean by Zhang et al. (2001) zonally averaged surface air temperature in the tropics declined by up to $0.2^{\circ} \mathrm{C}$ in response to tropical deforestation. Studying the response of a coupled atmosphere-ocean GCM to historical land cover changes, Feddema et al. (2005) have found a decrease in zonally averaged surface air temperature in the tropics by $0.2^{\circ} \mathrm{C}$, in line with EMIC simulations. Besides, deforestation in tropical regions in the HD simulation is rather minor relative to the temperate and boreal deforestation (Fig. 1b). There is apparent consensus between EMICs and GCMs that deforestation in the snow covered regions leads to a decrease in annually averaged temperature. For example, Feddema et al. (2005) showed stronger cooling in the northern midlatitudes than in the tropics, especially over the land, and maximum cooling of $1{ }^{\circ} \mathrm{C}$ over the Arctic.

In the design of the HD simulation we have interpreted cropland changes as changes in forest cover. While this approach is valid on a global scale, patterns of deforestation and cropland differ on a regional scale. This leads in particular to underestimation of recent deforestation in the tropical regions. This limitation of our study is caused by an absence of a global dataset of historical land cover changes highly resolved in time and space. The global synthesis of land cover changes in the past is also a missing key to testing hypotheses of the human influence on climate through land cover changes (e.g., Ruddiman 2003).

In the future, the biogeophysical effects of land cover changes will likely be different from what has occurred historically because of different spatial patterns of land use. Most areas that have been deforested in the past are located in the northern temperate latitudes, while in the future most of forest conversion to cropland is projected to be in the tropics. Simulations with the CSU GCM model coupled to the $\mathrm{SiB} 2$ biosphere model in response to the IPCC land-cover scenario SRES B revealed a warming over tropical regions due to land clearing and some cooling in the areas not affected by land conversion (DeFries et al. 2002). CLIMBER simulations with IPCC SRES scenarios suggest that future land cover scenarios may lead to biogeophysical warming as well as cooling depending on the scenario of land cover changes (Sitch et al. 2005), see Table 4. Since the biogeophysical effect of land cover changes might be comparable to biogeochemical effect of $\mathrm{CO}_{2}$ emissions due to deforestation (Brovkin et al. 2004; Matthews et al. 2004), they both need to be accounted for during assessments of $\mathrm{CO}_{2}$ mitigation options which include land conversion.

\section{Conclusions}

Learning lessons from the past is crucially important in order to provide a solid basis for projections of future climate change. Our study demonstrates that anthropogenic change in land cover has been a substantial climate forcing during the last several centuries. Forced by a consistent scenario of historical land cover changes, 
six EMIC models reveal a biogeophysical cooling effect within a range of $0.13-0.25^{\circ} \mathrm{C}$ on a global scale. This effect is comparable with a greenhouse effect of $\mathrm{CO}_{2}$ released during land conversion (Brovkin et al. 2004; Matthews et al. 2004).

In the future, land conversion may occur for reasons that are different from the causes of historical land cover changes. In particular, reforestation might be chosen as an option for the enhancement of terrestrial carbon sequestration. Our results indicate that biogeophysical mechanisms need to be accounted for in the assessment of land management options for climate change mitigation, as well as in the studies of detection and attribution of climate change, which usually neglect these effects of land cover change. In further analysis of effect of land cover changes on climate, the challenge will be to apply models of different complexity in complementary ways, exploiting both the computational efficiency of the EMICs and the state-of-the-art sophistication of GCMs.

Acknowledgements Part of this research was performed within the Second Multiannual Scientific Support Plan for a Sustainable Development Policy of the Belgian State.

\section{References}

Alcamo J, Leemans R, Kreileman EE (1998) Global change scenarios in the 21st century: results from the IMAGE 2.1 model, vol. Elseviers Science, London

Bauer E, Claussen M, Brovkin V, Huenerbein A (2003) Assessing climate forcings of the Earth system for the past millennium. Geophys Res Lett 30:1276. DOI 10.1029/2002GL016639

Bertrand C, Loutre MF, Crucifix M, Berger A (2002) Climate of the last millennium: a sensitivity study. Tellus A Dyn Meteorol Oceanogr 54:221-244

Betts RA (2000) Offset of the potential carbon sink from boreal forestation by decreases in surface albedo. Nature 408:187-190

Betts RA (2001) Biogeophysical impacts of land use on present-day climate: near-surface temperature change and radiative forcing. Atmos Sci Lett 2:39-51. DOI 10.1006/asle.2001.0023

Bonan GB (1999) Frost followed the plow: Impacts of deforestation on the climate of the United States. Ecol Appl 9:1305-1315

Bonan GB, Pollard D, Thompson SL (1992) Effects of boreal forest vegetation on global climate. Nature 359:716-718

Brovkin V, Ganopolski A, Claussen M, Kubatzki C, Petoukhov V (1999) Modelling climate response to historical land cover change. Glob Ecol Biogeogr 8:509-517

Brovkin V, Ganopolski A, Svirezhev Y (1997) A continuous climate-vegetation classification for use in climate-biosphere studies. Ecol Model 101:251-261

Brovkin V, Sitch S, von Bloh W, Claussen M, Bauer E, Cramer W (2004) Role of land cover changes for atmospheric CO2 increase and climate change during the last 150 years. Global Change Biol 10:1253-1266

Chase TN, Pielke RA, Kittel TGF, Nemani RR, Running SW (2000) Simulated impacts of historical land cover changes on global climate in northern winter. Clim Dyn 16:93-105

Claussen M, Brovkin V, Ganopolski A (2001) Biogeophysical versus biogeochemical feedbacks of large-scale land cover change. Geophys Res Lett 28:1011-1014

Claussen M, Mysak LA, Weaver AJ, Crucifix M, Fichefet T, Loutre MF, Weber SL, Alcamo J, Alexeev VA, Berger A, Calov R, Ganopolski A, Goosse H, Lohmann G, Lunkeit F, Mokhov
II, Petoukhov V, Stone P, Wang Z (2002) Earth system models of intermediate complexity: closing the gap in the spectrum of climate system models. Clim Dyn 18:579-586

Colman R (2003) A comparison of climate feedbacks in general circulation models. Clim Dyn 20:865-873

Crowley TJ (2000) Causes of climate change over the past 1000 years. Science 289:270-277

Crucifix M, Loutre MF, Tulkens P, Fichefet T, Berger A (2002) Climate evolution during the Holocene: a study with an Earth system model of intermediate complexity. Clim Dyn 19:43-60

DeFries RS, Bounoua L, Collatz GJ (2002) Human modification of the landscape and surface climate in the next fifty years. Global Change Biol 8:438-458

DeFries RS, Townshend JRG (1994) NDVI-derived land-cover classifications at a global-scale. Int J Remote Sens 15:3567-3586

Delire C, Behling P, Coe MT, Foley JA, Jacob R, Kutzbach J, Liu ZY, Vavrus S (2001) Simulated response of the atmosphereocean system to deforestation in the Indonesian Archipelago. Geophys Res Lett 28:2081-2084

Feddema J, Oleson K, Bonan G, Mearns L, Washington W, Meeh G, Nychka D (2005) A comparison of a GCM response to historical anthropogenic land cover change and model sensitivity to uncertainty in present-day land cover representations. Clim Dyn 25:581-609. DOI 10.1007/s00382-005-0038-z

Foley JA, Costa MH, Delire C, Ramankutty N, Snyder P (2003) Green surprise? How terrestrial ecosystems could affect earth's climate. Front Ecol Environ 1:38-44

Gallée H, van Ypersele JP, Fichefet T, Tricot C, Berger A (1991) Simulation of the last glacial cycle by a coupled, sectorially averaged climate-ice sheet model. Part I: the climate model. J Geophys Res 96:13:139-113,161

Ganopolski A, Petoukhov V, Rahmstorf S, Brovkin V, Claussen M, Eliseev A, Kubatzki C (2001) CLIMBER-2: a climate system model of intermediate complexity. Part II: model sensitivity. Clim Dyn 17:735-751

Goosse H, Fichefet T (1999) Importance of ice-ocean interactions for the global ocean circulation: a model study. J Geophys Res 104:23337-23355

Goosse H, Renssen H, Timmermann A, Bradley RS (2005) Internal and forced climate variability during the last millennium: a model-data comparison using ensemble simulations. Quaternary Sci Rev 24:1345-1360

Hansen J, Sato M, Lacis A, Ruedy R, Tegen I, Matthews E (1998) Perspective: climate forcings in the industrial era. Proc Natl Acad Sci 95:12753-12758

Henderson-Sellers A, Dickinson RE, Durbidge TB, Kennedy PJ, McGuffie K, Pitman AJ (1993) Tropical deforestation-modeling local-scale to regional-scale climate change. J Geophys Res Atmos 98:7289-7315

Houghton RA, Hobbie JE, Melillo JM, Moore B, Peterson BJ, Shaver GR, Woodwell GM (1983) Changes in the carbon content of terrestrial biota and soils between 1860 and 1980: a net release of CO2 to the atmosphere. Ecol Monogr 53:235-262

IPCC (2001) Climate change 2001: The scientific basis. In: Houghton JT, Ding Y, Griggs DJ, Noguer M, van der Linden PJ, Dai X, Maskell K, Johnson C (eds) Contribution of working Group I to the third assessment report of the intergovernmental panel on climate change. Cambridge University Press, Cambridge

Kabat P, Claussen M, Dirmeyer PA, Gash JHC, de Guenni LB, Meybeck M, Vörösmarty CJ, Hutjes RWA, Lütkemeier S (eds) (2004) Vegetation, water, humans and the climate: A new perspective on an interactive system, Springer, Berlin

Keeling CD, Whorf TP (2005) Atmospheric $\mathrm{CO}_{2}$ records from sites in the SIO air sampling network. In Trends: a compendium of data on global change. Carbon Dioxide Information Analysis Center, Oak Ridge National Laboratory, U.S. Department of Energy, Oak Ridge, Tennesse, USA

Kleidon A, Fraedrich K, Heimann M (2000) A green planet versus a desert world: estimating the maximum effect of vegetation on the land surface climate. Clim Change 44:471-493 
Klein Goldewijk K (2001) Estimating global land use change over the past 300 years: The HYDE database. Global Biogeochem Cycles 15:417-433

Leemans R, Eickhout B, Strengers B, Bouwman L, Schaeffer M (2002) The consequences of uncertainties in land use, climate and vegetation responses on the terrestrial carbon. Sci China 45:126-142

Mann ME, Jones PD (2003) Global surface temperatures over the past two millennia. Geophys Res Lett 30:1820. DOI 10.1029/ 2003GL017814

Matthews E (1983) Global vegetation and land use: new high-resolution data bases for climate studies. J Clim Appl Meteor 22:474-487

Matthews HD, Weaver AJ, Eby M, Meissner KJ (2003) Radiative forcing of climate by historical land cover change. Geophys Res Lett 30:1055. DOI 10.1029/2002GL016098

Matthews HD, Weaver AJ, Meissner KJ, Gillett NP, Eby M (2004) Natural and anthropogenic climate change: incorporating historical land cover change, vegetation dynamics and the global carbon cycle. Clim Dyn 22:461-479

Myhre G, Myhre A (2003) Uncertainties in radiative forcing due to surface albedo changes caused by land-use changes. J Clim 16:1511-1524

Neftel A, Friedli H, Moor E, Lötscher H, Oeschger H, Siegenthaler U, Stauffer B (1994) Historical $\mathrm{CO}_{2}$ record from the Siple station ice core. In Trends: a compendium of data on global change. Carbon Dioxide Information Analysis Center, Oak Ridge National Laboratory, U.S. Department of Energy, Oak Ridge, Tennesse, USA

Nemani RR, Running SW, Pielke RA, Chase TN (1996) Global vegetation cover changes from coarse resolution satellite data. J Geophys Res Atmos 101:7157-7162

Opsteegh JD, Haarsma RJ, Selten FM, Kattenberg A (1998) ECBILT: a dynamic alternative to mixed boundary conditions in ocean models. Tellus A Dyn Meteorol Oceanogr 50:348-367

Petoukhov V, Claussen M, Berger A, Crucifix M, Eby M, Eliseev AV, Fichefet T, Ganopolski A, Goosse H, Kamenkovich I, Mokhov I, Montoya M, Mysak LA, Sokolov A, Stone P, Wang Z, Weaver AJ (2005) EMIC Intercomparison Project (EMIP$\mathrm{CO} 2$ ): Comparative analysis of EMIC simulations of climate, and of equilibrium and transient responses to atmospheric $\mathrm{CO} 2$ doubling. Clim Dyn; DOI 10.1007/s00382-00005-00042-00383

Petoukhov V, Ganopolski A, Brovkin V, Claussen M, Eliseev A, Kubatzki C, Rahmstorf S (2000) CLIMBER-2: a climate system model of intermediate complexity. Part I: model description and performance for present climate. Clim Dyn 16:1-17
Pitman AJ, Zhao M (2000) The relative impact of observed change in land cover and carbon dioxide as simulated by a climate model. Geophys Res Lett 27:1267-1270

Ramankutty N, Foley JA (1999) Estimating historical changes in global land cover: croplands from 1700 to 1992. Global Biogeochem Cycles 13:997-1027

Renssen H, Goosse H, Fichefet T (2003) On the non-linear response of the ocean thermohaline circulation to global deforestation. Geophys Res Lett 30:1061. DOI 10.1029/ 2002GL016155

Ruddiman WF (2003) The anthropogenic greenhouse era began thousands of years ago. Clim Change 61:261-293

Sitch S, Brovkin V, von Bloh W, van Vuuren D, Eickhout B, Ganopolski A (2005) Impacts of future land cover changes on atmospheric $\mathrm{CO}_{2}$ and climate. Global Biogeochem Cycles 19:GB2013. DOI 10.1029/2004GB002311

Snyder PK, Delire C, Foley JA (2004) Evaluating the influence of different vegetation biomes on the global climate. Clim Dyn 23:279-302

Sokolov AP, Stone PH (1998) A flexible climate model for use in integrated assessments. Clim Dyn 14:291-303

Vitousek PM, Mooney HA, Lubchenco J, Melillo JM (1997) Human domination of Earth's ecosystems. Science 277:494-499

Weaver AJ, Eby M, Wiebe EC, Bitz CM, Duffy PB, Ewen TL, Fanning AF, Holland MM, MacFadyen A, Matthews HD, Meissner KJ, Saenko O, Schmittner A, Wang HX, Yoshimori M (2001) The UVic earth system climate model: model description, climatology, and applications to past, present and future climates. Atmosphere-Ocean 39:361-428

Wilson MF, Henderson-Sellers A (1985) A global archive of land cover and soils data for use in general circulation climate models. J Clim 5:119-143

Zhang H, Henderson-Sellers A, McGuffie K (2001) The compounding effects of tropical deforestation and greenhouse warming on climate. Clim Change 49:309-338

Zhao M, Pitman AJ (2002) The impact of land cover change and increasing carbon dioxide on the extreme and frequency of maximum temperature and convective precipitation. Geophys Res Lett 29. DOI 10.1029/2001GL013476 